Niniejsza publikacja jest dostępna na licencji Creative Commons. Uznanie autorstwa-Użycie niekomercyjne-Bez utworów zależnych 3.0 Polska. Pewne prawa zastrzė̇one na rzecz autora. Zezwala się na wykorzystanie publikacji zgodnie z licencja - pod warunkiem zachowania niniejszej informacji licencyjnej oraz wskazania autora jako właściciela praw do tekstu. Treść licencji jest dostępna na stronie: http://creativecommons.org/licenses/by-nc-nd/3.0/pl/

Lingwistyka Stosowana 19: 4/2016, 77-89

\author{
Marcin LĄCZEK \\ Uniwersytet Warszawski
}

\title{
Glottodydaktyka dwujęzyczna: przegląd polskiej i angielskiej terminologii
}

\begin{abstract}
:
Bilingual glottodidactics: review of Polish and English terminology

The article is a review of Polish and English terminology functioning in the area of bilingual glotttodidactics. At its beginning, the author lays out some of the issues concerned with glottodidactics, (applied) linguistics and didactics (methodology) of foreign language teaching. In the further course, the concept of bilingualism is defined with the areas in need of particular attention being immersion and submersion, followed by other typology of bilingual education.
\end{abstract}

\section{Wstęp}

Niniejszy artykuł, po nakreśleniu differentia specifica istniejących pomiędzy glottodydaktyką, lingwistyką (stosowaną) a dydaktyką (metodyką) nauczania języków obcych, zawiera przegląd polsko- i angielskojęzycznej terminologii funkcjonującej w obszarze glottodydaktyki dwujęzycznej.

Po przywołaniu definicji dwujęzyczności wraz z typologią, autor w dalszej części poddaje szerszej analizie zjawisko immersji i submersji. Zastrzec należy, iż publikacja nie ma na celu dokonania wszechstronnego i wyczerpującego opisu przedmiotowego zagadnienia, a jedynie jego zasygnalizowanie, bowiem w świetle niepodważalnej redundancji trudno jest przytoczyć nawet w dużym skrócie choćby najważniejsze definicje rzeczonego pojęcia proponowane w literaturze glottodydaktycznej, które wyłoniły się przy próbie dokonania syntezy definicji i opisów.

\section{Lingwistyka (stosowana) a glottodydaktyka}

Glottodydaktyka (glottodidactics), jak podaje F. Grucza (2013a: 221-228), jest dziedziną koncentrującą swe zainteresowania badawcze przede wszystkim na naukowym poznaniu procesów, jakie przebiegają w układzie glottodydaktycznym podczas nauki języka. S. Grucza (2013b: 6) z kolei dopełniając rzeczoną definicję zauważa, że glottodydaktyka, która ukonstytuowała się jako samodzielna nauka w drugiej połowie XX wieku, zajmuje się nauczaniem języków obcych, uczeniem się języków obcych oraz kształceniem nauczycieli języków obcych. Warto przy tym zauważyć, że według 
W.T. Miodunki (2009: 77-78), ,termin glottodydaktyka funkcjonuje z jednym ograniczeniem: odnosi się on do nauczania języków obcych, a nie do nauczania języków w ogóle (w tym - języka ojczystego, jak to pierwotnie proponował prof. F. Grucza) ${ }^{1}$."

Uniwersytet im. Adam Mickiewicza w Poznaniu był miejscem, w którym za sprawą L. Zabrockiego narodziła się polska glottodydaktyka - postrzegana zresztą przez poznańskich lingwistów jako dziedzina lingwistyki stosowanej, a miejscem, w którym w prekursorski sposób zaczęto posługiwać się rzeczoną nazwą był powołany do życia przez prof. F. Gruczę Instytut Lingwistyki Stosowanej Uniwersytetu Warszawskiego $^{2}$. L. Zabrocki, jak podaje F. Grucza (2013a: 221), używał jednak określenia metodyka lub dydaktyka nauczania języków obcych. Istotnym także jest fakt, że powiązał on glottodydaktykę nie z pedagogiką czy dydaktyką ogólną a z lingwistyką. F. Grucza (2013a: 223) z kolei traktuje glottodydaktykę jako dziedzinę ,(względnie) autonomiczną", a nie część składową lingwistyki (stosowanej) czy dydaktyki uzasadniając przy tym, że zarówno lingwistyka, glottodydaktyka i dydaktyka ogólna, primo, zajmują się różnymi przedmiotami, a, sekundo, ,glottodydaktykę (stanowiący ją ciąg pracy poznawczej) trzeba podzielić na etap (płaszczyznę) badań czystych i na etap (płaszczyznę) badań stosowanych (aplikatywnych)."

Zatem według założeń uczelni poznańskiej glottodydaktyka tożsama była z metodyką nauczania języków obcych, podczas gdy koncepcja warszawska zakładała, że jej głównym celem jest badanie funkcjonowania jednego ze szczególnych rodzajów (pewnej kategorii) układów komunikacyjnych, które F. Grucza nazwał - jak przywołano powyżej - układami glottodydaktycznymi:

[i]ch główne (konstytutywne) elementy (składniki) stanowią z jednej strony uczniowie, a z drugiej nauczyciele języków, ale nie tylko języków obcych, lecz także ojczystych. Prymarnym zadaniem glottodydaktyki jest rekonstrukcja specyficznych właściwości (zdolności, umiejętności) obu konstytutywnych współczynników tych układów, a więc nie tylko nauczycieli, lecz także, a w gruncie rzeczy w pierwszej kolejności, uczniów występujących w tego rodzaju układach komunikacyjnych (F. Grucza 2013a: 221),

a metody nauki języków obcych stanowią jeden z elementów badawczych tak pojmowanej glottodydaktyki (inny stanowić mogą np. materiały do nauki języków, w tym języków obcych).

Wypada zatrzymać się na chwilę nad samym pojęciem rekonstrukcji ${ }^{3}$. Otóż S. Grucza (2013a: 106) uczenie się, przyswajanie czy też akwizycję na gruncie teorii antropocentrycznej nazywa rekonstrukcją zarówno w odniesieniu do idiolektu podstawowego jak i specjalistycznego: ,[r]ekonstrukcja idiolektu specjalistycznego, tak samo jak rekonstrukcja idiolektu podstawowego, odbywa się w oparciu o właściwości

\footnotetext{
${ }^{1}$ Szkolnym procesem akwizycji, rozwijaniem i doskonaleniem kompetencji językowej i komunikacyjnej w języku ojczystym/pierwszym zajmuje się lingwodydaktyka (J. Nocoń 2012). ${ }^{2}$ W 1972 roku prof. F. Grucza użył wyrazu glottodydaktyka w tytule pierwszego z zorganizowanych przeze siebie (ILS UW) sympozjów pod nazwą „Lingwistyka stosowana i glottodydaktyka" (F. Grucza 2013a: 222).

${ }^{3}$ J. Sokol (2015) ,naukę” (pierwszego) języka zastępuję terminem jego „konstruowania” (przy pomocy metody prób i błędów oraz osób dorosłych).
} 
lingwogeneratywne (biologiczno-genetyczne) mówców-słuchaczy." Poza tym, jak dodaje dalej autor (2013a: 145):

rzeczywiste języki (idiolekty) konkretnych osób, czyli także rzeczywiste języki (idiolekty) specjalistyczne konkretnych specjalistów nie są czymś, co zostało komukolwiek 'nadane z góry', że każdy człowiek musi wytworzyć ('przyswoić sobie') sam swój język (idiolekt) i tylko on sam może go rozwijać. Po drugie to, co nazywa się 'przyswajaniem języka' jest procesem, w którym każdy człowiek 'wytwarza' (swój własny) rzeczywisty język w oparciu o specyficzny rodzaj biologiczno-genetycznych właściwości lingwogeneratywnych i że zarazem uczenie się języka 'obejmuje' proces generowania językowej wiedzy o świecie - proces poznawania świata, że już na tym poziomie języki ludzkie 'spełniają' istotne funkcje kognitywne.

Na koniec tej części wypada jeszcze przywołać kilka słów o samej lingwistyce (stosowanej) (applied linguistics). Otóż jako pierwszy w skali światowej lingwistykę stosowaną wyodrębnił i oddzielił od lingwistyki czystej pod koniec XVIII wieku niemiecki językoznawca August Ferdinand Bernhardi; drugi, w kolejności chronologicznej, był polski uczony Jan Niecisław Ignacy Baudouin de Courtenay (F. Grucza 2013a: 49-50). Jak dalej zauważa F. Grucza (2013a: 185) data ukazania się dzieła A.F. Bernhardiego nie wyznacza początku historii lingwistyki stosowanej w ogóle a jedynie „(a) początek historii świadomego wyodrębniania lingwistyki stosowanej i tym samym dzielenia ogólnego zakresu lingwistyki na lingwistykę czystą i stosowaną oraz (b) początek wyraźnego zaliczania pewnych zagadnień do zbioru zadań lingwistyki stosowanej." Co więcej, również data (1870) wygłoszenia przez J. N. I. Baudouina de Courtenay jego słynnego petersburskiego wykładu nie jest tożsama z początkiem historii polskiej (meta)lingwistyki stosowanej w ogóle (F. Grucza 2013a: 187). F. Grucza (2013a: 117) odrzuca twierdzenie, że różnica między tymi poddziedzinami polega na tym, iż lingwistyka czysta ma cele wyłącznie poznawcze, a lingwistyka stosowana - praktyczne argumentując, że charakter poznawczy mają obie: „tworzenie wiedzy i tylko wiedzy", przy czym jest to tworzenie różnych rodzajów wiedzy.

\section{Pojęcie dwujęzyczności}

Nawet w dużym skrócie trudno jest przytoczyć proponowane w literaturze glottodydaktycznej definicje pojęcia bilingwizmu (bilingualism) bowiem jest to pojęcie złożone, obejmujące szereg różnych elementów ze sfery uczącego i uczącego się. Poniższe słowa M. Olpińskiej-Szkiełko (2013b: 50) ${ }^{4}$ stanowią dowód tej niepodważalnej redundancjis:

\footnotetext{
${ }^{4} \mathrm{~W}$ swojej pracy poświęconej rozwojowi językowemu, poznawczemu, emocjonalnemu i społecznemu dziecka, M. Olpińska-Szkiełko (2013b) przedstawia najważniejsze wyniki badań naukowych na temat przyswajania mowy, dwujęzyczności i wychowania dwujęzycznego (z uwzględnieniem rysu historycznego tych badań i szczególnym wyeksponowaniem osiągnięć dokonanych w Polsce).

${ }^{5}$ S. Grucza (2013b: 23), w oparciu o sposób ujmowania relacji pomiędzy językami specjalistycznymi a językiem, zaprezentowany przez F. Gruczę (język ogólny i języki specjalistyczne nie są językami funkcjonalnie kompatybilnymi, lecz komplementarnymi) sugeruje, że trzeba je traktować jako języki w dużej mierze, zwłaszcza funkcjonalnie, odrębne, co może z kolei
} 
[w]łaściwie każdy z autorów zajmujących się problematyką dwujęzyczności tworzy własną terminologię lub używa określeń proponowanych przez innych badaczy, rozumiejąc je inaczej i 'wypełniając' innymi znaczeniami. Może to prowadzić do wielu nieporozumień, dlatego na wstępie rozważań o dwujęzyczności należy zwrócić uwagę na te nieścisłości. Jako synonimy funkcjonują następujące pojęcia: 'dwujęzyczność' oraz 'bilingwizm', a w odniesieniu do kilku języków - 'wielojęzyczność' lub 'multilingwizm'.

W odróżnieniu od zarysowanego powyżej pojęcia dwujęzyczności i wielojęzyczności (multilingualism), dodać należy, że w wyniku prac prowadzonych przez Radę Europy, implikujących zmianę w podejściu do kształcenia językowego, funkcjonować zaczęło pojęcie różnojęzyczności (plurilingualism). Celem użytkownika różnojęzycznego nie jest już osiągnięcie perfekcji w danym języku/danych językach na wzór idealnego rodzimego użytkownika, a jedynie, rozwinięcie językowej kompetencji w myśl założenia, że

kolejne doświadczenia językowe i kulturowe indywidualnego człowieka, począwszy od języka domu rodzinnego i szerszej społeczności aż po języki innych narodów (czy to nauczane w szkole, czy też poznawane w bezpośrednim kontakcie), nie są gromadzone w postaci odrębnych modułów, lecz składają się na jedną całościową kompetencję komunikacyjną, w której wszystkie te doświadczenia i języki wzajemnie się przenikają i na siebie wpływają. (Europejski system opisu kształcenia językowego: uczenie się, nauczanie, ocenianie 2003).

M. Olpińska-Szkiełko (2013b) podkreśla, że wczesny kontakt z językiem innym niż język ojczysty może mieć (przy założeniu, że spełnione zostaną pewne warunki) bardzo dobry wpływ na językowy, poznawczy, emocjonalny i społeczny rozwój dziecka. Istotnym przy tym jest także fakt, że, w optyce autorki (2013b: 20), rozwój językowy tożsamy jest z rozwojem dziecka w ogóle, bowiem język jest wyłącznie ludzką właściwością (tu: konkretnego dziecka) i nie może być rozpatrywany w oderwaniu od niego, co udowodnił w swoich pracach nad teorią antropocentryczną ${ }^{6}$ przywołany już kilkakrotnie powyżej F. Grucza (2013a, 2013b). F. Grucza (1981) wyróżnił dwie fazy procesu akwizycji języka: a) równoczesną, obejmującą okres wczesnego dzieciństwa (wiek od 0 do 4 lat) i b) konsekutywną, obejmującą okres późnego dzieciństwa (wiek od 5/7 lat do 11 roku życia).

Na potrzeby niniejszego referatu wystarczy tylko przypomnieć definicję L. Bloomfielda (1933) głoszącego, że osoba bilingwalna posiada pełną biegłość w dwóch językach, F. Grosjeana (1989) określającego osobę dwujęzyczną jako kogoś kto potrafi funkcjonować w każdym języku według danych potrzeb, czy E. Bialystok (2001), zdaniem której bilingwalne dziecko zdaje się funkcjonować w równym stopniu w dwóch językach, poruszać pomiędzy nimi bez wysiłku, i przybierać odpowiednią społeczno-kulturową postawę dla każdego języka. Zestawiając powyższe określenie z definicją dwujęzyczności E. Lipińskiej i A. Seretny nie zauważamy jakichś differentia specifica, gdyż zdaniem Autorek (2012: 27-28) dwujęzyczność:

prowadzić do konkluzji, że „mówcę słuchacza Polaka znającego zarówno ogólny język polski, jak i jakiś polski język specjalistyczny trzeba traktować w pewnym sensie jako osobę bilingwalną (...)" (S. Grucza 2013b: 22-23).

${ }^{6}$ Teoria antropocentryczna zakłada, że rzeczywiście istnieją tylko konkretne języki (idiolekty) konkretnych (rzeczywistych) ludzi (S. Grucza 2013a: 106). 
to opanowanie dwu języków przez daną osobę w takim stopniu, jak wiekowo i społecznie jej odpowiadający ich rodzimi użytkownicy. Polega na umiejętności posługiwania się wszystkimi sprawnościami w języku ojczystym i drugim oraz na częstym i swobodnym ich używaniu w różnych sytuacjach i z różnymi uczestnikami aktu komunikacji. Wiąże się ona także z bliskim kontaktem $\mathrm{z}$ obydwiema kulturami i możliwością ich doświadczania (doznawania).

Zatem dokonując syntezy definicji i opisów pojęcia dwujęzyczności spotykanych w literaturze, należy stwierdzić, że są one bardzo liczne, ale i zbieżne, i z łatwością można w nich odnaleźć wspólne pojęcia kluczowe. Warto w tym miejscu przypomnieć, że pionierskie badania nad rozwojem dwujęzyczności rozpoczął francuski psycholog J. Ronjat, a później W. F. Leopold; w obu przypadkach przeprowadzane były one w pierwszej połowie ubiegłego stulecia (odpowiednio w roku $1913 \mathrm{i}$ w latach 1939-1949). Niezależnie od tego, kim są ich autorzy (chodzi o kraj pochodzenia) i jakiego języka (języków) dotyczą, w definicjach kładzie się akcent na znajomość dwóch języków (ojczystego i drugiego) ${ }^{7}$ opanowanych adekwatnie do wieku i statusu społecznego. Rzetelnego, syntetycznego przeglądu terminologii stosowanej w glottodydaktyce polonistycznej z równoczesnym wyjaśnieniem uwarunkowanych kontekstowo, tj. środowiskiem endo- lub egzolingwalnym, przedmiotowych terminologicznych niuansów dokonały E. Lipińska oraz A. Seretny (2012: 19-31) poddając analizie takie terminy jak: język ojczysty, język pierwszy, język rodzimy, język prymarny, język etniczny, język narodowy, język odziedziczony, język wyjściowy, język docelowy, język obcy czy język drugi - nie będę więc ich tutaj streszczać ponownie.

E. Lipińska i A. Seretny (2012: 28-29) zwracają uwagę na konieczność odróżnienia pojęcia bilingwizmu od: a) znajomości dwóch języków (knowledge of two languages) (będącego pojęciem szerszym od dwujęzyczności), a które zakłada, że ,język ojczysty nie jest opanowywany stosownie do wieku i statusu społecznego (...), a kompetencja osiągnięta w języku innym nie odbiega od umiejętności językowych rodzimych użytkowników języka, będących w tym samym wieku i mających ten sam status społeczny" oraz b) dyglosji (diglossia) pojmowanej jako umiejętność posługiwania się dwiema odmianami języka; wyróżnia się tu wersję niską jaką jest odmiana kontaktowa lub regionalno-kontaktowa stosowana w środowisku domowym oraz wysoką, czyli język ogólnonarodowy. Przykładem pierwszej jest język polonijny, drugiej język polski ${ }^{8}$.

\footnotetext{
${ }^{7}$ Warto w tym miejscu wspomnieć o przypadkach nie stanowiących już (w obecnych czasach) swoistego obszaru terra incognita, tj. gdy dana osoba dwujęzyczna posługuje się jednym językiem mówionym (np. angielskim jako językiem ojczystym) i językiem migowym jako drugim (np. American Sign Language, ASL: amerykańskim językiem migowym czy British Sign Languge, BSL: brytyjskim językiem migowym) nieustępującemu w żadnej mierze językowi naturalnemu (E.S. Klima/ U. Bellugi 1979) - mamy wówczas do czynienia z dwujęzycznością bimodalną (bimodal bilingualism).

${ }^{8}$ Innym przykładem może być zestawienie języków: arabskiego i malezyjskiego (E. Bialystok 2001). Poza tym, jednostka może posiadać umiejętności dwudialektalne (bidialectal) lub dwuskryptowe (biscriptual); przykładem obydwu może być język chiński (A. Lam 2006).
} 


\section{Typologia dwujęzyczności}

Podkreślić należy, że poniżej zaprezentowany podział nie ma na celu dokonania wszechstronnego i wyczerpującego opisu omawianego zagadnienia. Niemiej jednak, mając na uwadze feerię przemieszanych kontekstów i punktów odniesienia podejmowanych w literaturze przedmiotu rozróżnić można pomiędzy dwujęzycznością ${ }^{9}$ : addytywną lub wzbogacającą (additive bilingualism): dziecko nabyło umiejętność posługiwania się dwoma językami, cieszącymi się jednakowym prestiżem społecznym, w równym stopniu, co przekłada się na rozwój jego zdolności poznawczych; zrównoważoną (balanced/perfect bilingualism): stopień kompetencji w obu językach, w tych samych okolicznościach, jest taki sam ${ }^{10}$; uzupełniającą (complementary bilingualism): jeden język jest używany w niektórych dziedzinach życia codziennego, a drugi - w pozostałych; pełną (complete/full bilingualism): kompetencja językowa i komunikacyjna są rozwinięte $\mathrm{w}$ obu językach zarówno $\mathrm{w}$ mowie, jak i w piśmie ${ }^{11}$; złożoną lub mieszaną (compound bilingualism): wspólny system znaczeń odpowiada wyrazom w języku ojczystym i drugim; sukcesywną (consecutive/successive bilingualism): drugi język został wprowadzony po upływie trzeciego roku życia ${ }^{12}$; współrzędną lub czystą (coordinate bilingualism): odrębny system znaczeń odpowiada wyrazom w języku ojczystym i drugim; uśpioną (dormant bilingualism): jeden z języków nie jest regularnie stosowany, co prowadzi do wystąpienia oznak zapominania go włącznie; funkcjonalną (functional bilingualism): poszczególne sprawności językowe w języku ojczystym i drugim są rozwinięte w różnym stopniu, w wyniku czego jeden $\mathrm{z}$ nich staje się językiem słabszym (weaker language), a drugi językiem dominującym (dominant language) - nie wpływa to jednak na swobodne funkcjonowanie w obydwu językach; jednostkową (individual bilingualism): znajomość dwóch języków: ojczystego i drugiego opanowanych adekwatnie do wieku i statusu społecznego w wymiarze indywidualnym; pierwotną (natural bilingualism): dziecko opanowało dwa języki w otoczeniu naturalnym jednocześnie przed ukończeniem trzech lat lub jeden do trzeciego roku życia, a drugi po tym okresie; produktywną (productive bilingualism):

\footnotetext{
${ }^{9}$ Zachowano porządek alfabetyczny - kryterium stanowił język angielski.

${ }^{10} \mathrm{~W}$ pokoleniu polonijnym brak znajomości socjolektu społecznie ekwiwalentnej grupy wiekowej wyklucza dwujęzyczność zrównoważoną (W. T. Miodunka, 2010) pojmowaną przez E. Lipińską (2013: 103) jako „kompetencję natywną lub prawie natywną we wszystkich sprawnościach w dwu językach".

${ }^{11}$ Jeśli dana osoba nie opanowała umiejętności czytania i pisania, wówczas jest dwujęzycznie zrównoważona, ale nie w pełni.

12 Dwujęzyczność wczesna konsekutywna (early successive/consecutive bilingualism) ma miejsce, gdy dziecko dorasta w rodzinie, która posługuje się językiem ojczystym, a z językiem drugim spotyka się $\mathrm{w}$ środowisku sformalizowanym, tj. $\mathrm{w}$ przedszkolu lub $\mathrm{w}$ szkole lub poprzez kontakt $\mathrm{z}$ otoczeniem obcojęzycznym. Istnieje $\mathrm{w}$ literaturze pojęcie dwujęzyczności szkolnej (school bilingual education) pojmowanej jako nauka drugiego języka na kursach i w szkołach w kraju ojczystym. Wreszcie, dla porównania, warto w tym miejscu przywołać również pojęcie dwujęzyczności dorosłych (adult bilingualism), czyli przyswajanie drugiego języka w naturalny sposób poprzez kontakt ze środowiskiem mówiącym tym językiem. Warto dodać, że, jak wykazały badania, dorosłe osoby dwujęzyczne przejawiają silne tendencje do liczenia i modlenia się w języku, w którym po raz pierwszy nauczyły się wykonywać te czynności (B. Spolsky 1998).
} 
zdolność posługiwania się dwoma językami przy kompetencji rozwiniętej do pewnego stopnia; rzeczywistą (real bilingualism): dana jednostka opanowuje obydwa języki od wczesnego dzieciństwa i ma podobną łatwość w komunikowaniu się w obu; receptywną (receptive bilingualism): zdolność rozumienia dwóch języków przy jednoczesnym opanowaniu różnych umiejętności (tu: receptywnych); równoczesną ( $s i$ multaneous bilingualism): drugi język został wprowadzony przed trzecim rokiem życia $^{13}$; społeczną (societal bilingualism): znajomość dwóch języków: ojczystego i drugiego opanowanych adekwatnie do wieku i statusu społecznego w wymiarze społecznym; podporządkowaną (subordinate bilingualism): dostęp języka drugiego do systemu znaczeń za pomocą języka ojczystego; subtraktywną lub zubażającą (subtractive bilingualism): dziecko rozwinęło umiejętności porozumiewania się w języku drugim kosztem rozwoju umiejętności w języku ojczystym, który nie cieszy się jednakowym prestiżem społecznym ${ }^{14}$, co z kolei wywołuje negatywny skutek na jego rozwój poznawczy; ukrytą (transitional bilingualism) stopniowe zastępowanie języka ojczystego językiem drugim będącego językiem dominującym (T. K. Bhatia/ W.C. Ritchie 2004, Bialystok, 2001, S. Döpke 1992, F. Grosjean, 1982, A. Lam 2006, E. Lipińska/ A. Seretny 2012, I. Kurcz 2007, E. Peal/ W.E. Lambert, 2007) ${ }^{15}$.

Mając powyższe na uwadze, S. Romaine (1989) wyróżnia sześć rodzajów akwizycji językowej w dzieciństwie: 1) jedna osoba - jeden język (one person - one language $)^{16}$ : rodzice posługują się różnymi językami ojczystymi, ale każdy z nich posiada pewien stopień kompetencji w języku drugiego; język jednego z rodziców jest dominującym językiem społeczeństwa - każdy z nich zwraca się w swoim języku do dziecka od urodzenia, 2) niedominujący język domowy (non-dominant home language): rodzice posługują się różnymi językami ojczystymi, ale język jednego z nich jest dominującym językiem społeczeństwa; oboje rodzice mówią do dziecka w języku niedominującym, które $\mathrm{z}$ kolei ma pełny kontakt $\mathrm{z}$ językiem dominującym tylko poza domem - w szczególności w przedszkolu, 3) niedominujący język domowy bez wsparcia społeczeństwa (non-dominant home language without the community support): oboje rodzice posługują się tym samym językiem ojczystym, który nie jest językiem dominującym - rodzice mówią do dziecka w swoim języku, 4) podwójny niedominujący język domowy bez wsparcia społeczeństwa (double non-dominant home language without the community support): oboje rodzice posługują się różnymi

\footnotetext{
${ }^{13}$ Dwujęzyczność wczesna symultaniczna (early simultaneous bilingualism) ma miejsce, gdy dziecko styka się z dwoma językami w stadium nauki mówienia.

${ }^{14}$ Przykładowe warianty szacowania prestiżu języka ojczystego i języka drugiego widzianego poprzez pryzmat solidarności z daną grupą (własną lub obcą) przez przedstawicieli grupy większościowej posługującej się językiem ojczystym i grupy mniejszościowej posługującej się językiem drugim omawia np. E. Bouchard Ryan i H. Giles (1982).

15 Trzy typy systemu pamięci dwujęzycznej opracowanej przez U. Weinreicha (1953) to: a) dwujęzyczność współistniejąca (coexistent bilingualism) zakładająca, że dwa języki, przyswajane w różnych środowiskach, są odrębne, b) dwujęzyczność połączona (merged bilingualism) zakładająca, że dwa języki łączą się w jeden system, używany naprzemiennie, c) dwujęzyczność podporządkowana (subordinate bilingualism) zakładająca, że język drugi oparty jest na języku ojczystym. Koncepcja ta została następnie zmodyfikowana przez S. Erwina i C. Osgooda (1954).

16 Tłumaczenie moje, M.Ł.
} 
językami ojczystymi; dominujący język jest inny niż język któregokolwiek z rodziców, w którym zwracają się do dziecka od urodzenia, 5) rodzice posługują się tym samym językiem ojczystym (the parents share the same native language): język rodziców jest językiem dominującym - jedno z rodziców zawsze zwraca się do dziecka w języku, który nie jest jego/jej językiem ojczystym, 6) języki mieszane (mixed languages): rodzice są osobami dwujęzycznymi, sektory społeczne mogą również być bilingwalne; rodzice przełączają kody i mieszają języki.

I. Kurcz (2007) z kolei wspomina o trzech strategiach (modelach) nauczania dziecka języka drugiego takich jak: a) strategia osoby (one person, one language, OPOL), przy zastosowaniu której jedna osoba (jeden rodzic) zwraca się do dziecka tylko w języku ojczystym, a druga osoba (drugi rodzic) w języku drugim - strategia ta utożsamiana jest $\mathrm{z}$ dwujęzycznością równoczesną; b) strategia miejsca (minority language at home, ml@ $\mathrm{H}^{17}$ ), przy zastosowaniu której jeden język (zazwyczaj język ojczysty będący językiem mniejszościowym) jest używany w domu, a język drugi: w szkole - strategia ta utożsamiana jest z dwujęzycznością sukcesywną i, c) strategia czasu (time), przy zastosowaniu której w pewnych porach dnia (lub w pewnych dniach) wszyscy członkowie z otoczenia dziecka mówią w języku ojczystym, a w innych $-\mathrm{w}$ języku drugim ${ }^{18}$.

Istotnym w glottodydaktyce dwujęzycznej jest również pojęcie immersji (immersion), zwanej także dwujęzycznością wzbogacającą lub addytywną (additive bilingualism), która w literalnym przekładzie oznacza „zanurzenie” (tu: zanurzenie dziecka w nowym dla niego języku, tj. języku drugim). Prace w tym zakresie rozpoczęli na początku lat sześćdziesiątych ubiegłego wieku kanadyjscy uczeni: neuropsycholog W. Penfield i psycholog społeczny W. Lambert, którzy poddawali testom językowym angielskojęzyczne dzieci mieszkające w Montrealu (warto zwrócić uwagę na fakt, że $\mathrm{w}$ tamtym czasie to język francuski cieszył się tam znacznie mniejszym prestiżem). Wstępne wyniki poddawanych testom dzieci w obu językach były dosyć słabe w porównaniu do wyników osiągniętych przez ich jednojęzycznych rówieśników, i dopiero w późniejszym okresie ( $\mathrm{w}$ wieku 11 lat) dzieci zaczęły osiągać porównywalne rezultaty - w kilku testach z języka angielskiego były one nawet lepsze od ich kolegów angielskojęzycznych. Zebrane z badań wyniki ukazujące pozytywne oddziaływanie kształcenia dwujęzycznego na język ojczysty (uległ on wzbogaceniu), inteligencję i funkcjonowanie poznawcze dziecka zostały opublikowane przez E. Peal i W. E. Lamberta $(1962)^{19}$. Wbrew pierwotnym obawom nie doszło do wystąpienia submersji.

Kształcenie poprzez immersję realizowane jest w oparciu o specjalnie opracowane programy, na podstawie których nauczane są w szkołach jednojęzyczne dzieci,

\footnotetext{
${ }^{17} \mathrm{~F}$. Grosjean (2010) proponuje określenie: home - outside the home strategy.

18 Podobna do założeń strategii czasu jest strategia przemienna, przy zastosowaniu której okresy mówienia wyłącznie w języku ojczystym lub języku drugim są dłuższe (na przykład cały rok). Strategia czasu i strategia przemienna mogą być utożsamiane zarówno z dwujęzycznością równoczesną, jak i sukcesywną.

${ }^{19}$ Dla porównania, badania przeprowadzone przez M. Paradis $(2000,2004)$ dowiodły, że mózg osoby jednojęzycznej nie różni się niczym od mózgu osoby dwujęzycznej, a ewentualne różnice są jedynie następstwem stopnia, w którym mózg jest wykorzystywany.
} 
a w których środkiem instrukcji we wszystkich przedmiotach jest język drugi. Nauczycielami są rodzimi użytkownicy języka (drugiego) posiadający także pewną wiedzę z zakresu języka ojczystego i kultury poddawanych procesowi nauczania dzieci (M. Swain 1978) ${ }^{20}$. Warto odnotować, że w przypadku immersji język drugi nie zagraża prestiżem społecznym i zakresem stosowania językowi pierwszemu (E. Lipińska/ A. Seretny 2012: 88). W literaturze przedmiotu rozróżnia się pomiędzy immersją całkowitą (early total immersion) stanowiącą pełne zanurzenie w języku drugim, która w przypadku grup mniejszościowych uczących się języka dominującego może doprowadzić do ryzyka submersji oraz immersją częściową (early partial immersion), gdzie proporcjonalny stosunek posługiwania się językiem ojczystym i językiem drugim we wszystkich sytuacjach komunikacyjnych wynosi $50 \%{ }^{21}$.

Submersja (submersion), zwana także dwujęzycznością zubażającą lub subtraktywną (subtractive bilingualism) z kolei w literalnym przekładzie oznacza „zanurzenie, zatopienie" (tu: zatopienie/wchłonięcie języka ojczystego przez język drugi). Ze zjawiskiem submersji mamy do czynienia, gdy dziecko reprezentujące daną mniejszość etniczną posługującą się językiem ojczystym o niskim prestiżu społecznym uczy się przedmiotów szkolnych wraz z natywnymi rówieśnikami. W konsekwencji prowadzi to do zatracenia języka ojczystego, tj. nie osiągnięcia w nim pełnej kompetencji językowej. Może się także zdarzyć, że dziecko nie osiągnie pełnej kompetencji językowej również w języku drugim. $Z$ wyżej wymienionych powodów wielu psychologów w ubiegłym stuleciu uważało, że dwujęzyczność u dzieci wpływa niekorzystnie na ich rozwój poznawczy i intelektualny $y^{22}$.

Zatem, aby immersja nie przekształciła się w submersję powinny zostać spełnione określone warunki. F. Genessee $(1987,1994)$ zalicza do nich następujące okoliczności: a) dziecko wynosi z domu znajomość języka ojczystego, który jest językiem większości i posiada wysoki prestiż społeczny, b) nauczyciele i szkoła podtrzymują ten prestiż, c) dziecko samo ceni również swój język ojczysty i, na koniec, d) dziecko, szkoła i rodzice są zainteresowani nabyciem przez dziecko umiejętności w języku drugim.

\footnotetext{
${ }^{20}$ Inną odmianą kształcenia poprzez immersję jest program o nazwie sheltered English programme (sheltered oznacza: chroniony, ,pod kloszem)”, według założeń którego dzieci imigrantów, pochodzące $\mathrm{z}$ różnych środowisk językowych, są nauczane wszystkich przedmiotów w języku angielskim, a także uczęszczają na zajęcia z angielskiego jako języka drugiego (English as a second language, ESL) (H. D. Brown 1994).

${ }^{21}$ Metodologiczne podstawy opracowane podczas badań nad językową immersją znalazły ujście w zaproponowanym przez D. Marsha (1994) podejściu CLIL (content and language integrated learning), tj. zintegrowanym kształceniu przedmiotowo-językowym (zob. też D. Marsh/ A. Maljers/ A.K. Hartiala (2001), Profiling European CLIL Classrooms -Languages Open Doors, Jyväskylä) czy CBI (content-based instruction), tj. nauczaniu przez treść autorstwa D.M. Brintona, M.A. Snowa i M.B. Wesche (1997).

22 Przeciwieństwem modelu edukacji dwujęzycznej opartej na submersji jest program oparty na języku ojczystym (heritage language programme), który zakłada, że język niedominujący nie jest używany jako środek instrukcji, ale mimo to jest ceniony jako język docelowy lub model oparty na czasie kontaktu z językiem (language exposure time model), w którym język ojczysty danego użytkownika jest ceniony jako język docelowy i także używany jako środek instrukcji w nauczaniu niektórych przedmiotów szkolnych (A. Lam 2006).
} 


\section{Inne (istotne) pojęcia w glottodydaktyce dwujęzycznej}

Analizując pojęcia związane z bilingwizmem, trzeba jeszcze wspomnieć o fosylizacji (fossilisation), czyli zamrożonej kompetencji oraz półjęzyczności, tj. semilingwiźmie (semilinguism), czyli niedostatku kompetencji w dwu językach. Pierwsze zakłada, że „uczący się, osiągnąwszy pewien poziom znajomości języka (innego niż ojczysty), nie czyni dalszych postępów mimo sprzyjających warunków”, a drugie - „regres kompetencji w języku ojczystym, przy jednoczesnym jej zablokowaniu (zamrożeniu) w języku drugim" (E. Lipińska/ A. Seretny 2012: 29-30). Semilingwizm, jak zaznacza R. Laskowski (2014), może prowadzić do społecznej marginalizacji ze wszystkimi jej psychologicznymi i społecznymi konsekwencjami. Rodzice, zauważa dalej autor (2014), zwracając się do dziecka w języku drugim (dominującym), a więc w języku, który sami nie opanowali w stopniu dostatecznym, mogą doprowadzić do utraty znajomości języka ojczystego w drugim pokoleniu imigrantów i kulturowego oddzielenia się od kraju pochodzenia; strategia ta nazwana została ucieczką do przodu (forward escape strategy). Poza tym, funkcjonuje jeszcze koncept pseudobilingwizmu (pseudobilinguism) (E. Peal i W. E. Lambert 2007 w: E. Lipińska 2013) traktujący o znacznie lepszej znajomości jednego języka niż drugiego i używania go w codziennej komunikacji, i podwójnego analfabetyzmu (double illiteracy), w odniesieniu do którego R. Laskowski (2009) używa określenia „cofanie się” znajomości danego języka, a E. Lipińska (2013) definiuje jako niedorozwój umiejętności w języku ojczystym i drugim.

Innymi istotnymi pojęciami w glottodydaktyce dwujęzycznej, ściśle związanymi ze zjawiskiem ścierania się języków (language attrition) w obrębie tej samej społeczności, są jeszcze pojęcia: a) przełączania kodów (code switching) ${ }^{23}$, w wyniku którego pewne elementy leksykalne (pojedyncze wyrazy lub frazy) pochodzące z jednego języka są przejmowane przez język drugi ${ }^{24}$, b) zapożyczeń językowych (lexical borrowing), w wyniku którego pewne wyrazy, zwroty, typy derywatów, formy fleksyjne, konstrukcje składniowe czy związki frazeologiczne przechodzą z jednego języka do języka drugiego ${ }^{25}, \mathrm{c}$ ) konwergencji językowej (language convergence/linguistic alliance $)^{26}$, w wyniku której dochodzi do swoistego połączenia się dwóch języków przynależących do tego samego geograficznego obszaru mowy w jeden.

\footnotetext{
${ }^{23}$ Pojęcie przełączania języka (language switching) stosowane jest w strategiach komunikacji opartych na języku ojczystym w klasie gdzie język drugi jest nauczany jako język obcy (foreign language) (J. Majer 2003).

${ }^{24}$ Przełączanie kodu (code switching), w kontekście wielojęzyczności, jest naprzemiennym używaniem kilku języków (B. Bailey 2001). G. Liebscher i J. Dailey-O'Cain (2005) dodają, że może ono również dotyczyć systematycznego naprzemiennego używania odmian tego samego języka i mieć miejsce w obrębie jednej konwersacji lub wypowiedzi; na przykład zjawisko to może dotyczyć języka ojczystego w kontekście dychotomii: odmiana literacka a odmiana potoczna.

${ }^{25}$ Przełączanie języka ma wymiar jednostkowy, a w przypadku zapożyczeń językowych odnosimy się do członków danej społeczności; w obu przypadkach system językowy pozostaje nienaruszony (A. Lam 2006).

${ }^{26}$ Całkowite połączenie się języków skutkować może językiem mieszanym (mixed language),
} 


\section{Konkluzja i wnioski}

Celem niniejszej publikacji było zaprezentowanie przeglądu polskiej i angielskiej terminologii funkcjonującej w obszarze glottodydaktyki dwujęzycznej. Pionierskie badania nad rozwojem dwujęzyczności rozpoczął w pierwszej połowie ubiegłego wieku J. Ronjat (1913); na uwagę zasługują również osiągnięcia w tym obszarze dokonane przez W. F. Leopolda (1939-49) czy prace W. Penfielda i W. Lamberta zebrane i opublikowane przez E. Peal i W. E. Lamberta (1962). Późniejsze badania, z których wiele było studiami przypadku poszczególnych państw lub społeczeństw podkreślających uznanie historii, polityki czy demografii, powojenne ruchy migracyjne, postkolonialną politykę językową, propagowanie humanistycznych i egalitarnych ideologii (A. Lam 2006), potwierdzały kolejno, że dwujęzyczne dzieci nie różnią się w niczym od swoich jednojęzycznych rówieśników poza tym, że znają one dwa języki, a nie jeden (W. Klein 1986). Aczkolwiek, jak stwierdza E. Bialystok (2009), (dwu- i wielokulturowość i) dwujęzyczność mogą być zarówno niezwykle cennym bodźcem w procesie intelektualnego rozwoju dziecka, jak i ciężarem, który, w ekstremalnych przypadkach, prowadzi do socjopatycznego zachowania i opóźnień w rozwoju kognitywnym. M. Olpińska-Szkiełko (2013a: 146), również doceniając wagę kształcenia dwujęzycznego, z kolei uważa, że:

[n]ajbardziej zrównoważony i wszechstronny rozwój zarówno umiejętności językowych, w tym umiejętności intensywnego rozumienia - interpretacji - oraz tworzenia wypowiedzi ustnych i pisemnych, kompetencji terminologicznej i umiejętności analizy tekstu, jak i umiejętności niejęzykowych, w tym szczególnie kompetencji metodycznej, ale także umiejętności poznawczych, kompetencji interkulturowej, kompetencji medialnych oraz społecznych, ma miejsce $\mathrm{w}$ ramach nauczania dwujęzycznego, podobnie jak w pracy projektowej oraz dramie, $\mathrm{z}$ tym, że w tych ostatnich przypadkach nie tak ważną rolę odgrywa rozwój kompetencji metodycznej.

Na koniec, warto odnotować, że w latach siedemdziesiątych poprzedniego stulecia mamy do czynienia $\mathrm{z}$ rozkwitem wszelkiego rodzaju edukacyjnych inicjatyw propagujących nauczanie treści poprzez język, aniżeli uczenie się języka jedynie „dla zasady”. Rzeczone inicjatywy obejmowały m.in. takie programy jak: nauczanie języka poprzez program nauczania (Language Across the Curriculum, LAC) ${ }^{27}$, kształcenie poprzez immersję (Immersion Education, ImE), programy dla imigrantów (Immigrant On-Arrival Programs), programy dla uczniów z ograniczoną znajomością języka angielskiego (programs for Students with Limited English Proficiency, SLEP), czy wszelkiego rodzaju programy, których nadrzędnych celem było nauczanie języka specjalistycznego (Language for Specific Purposes, LSP), takie jak na przykład: angielski w nauce i technologii (English for Science and Technology, EST), angielski dla celów specjalistycznych (English for Specific Purposes, ESP), angielski dla celów zawodowych (English for Occupational Purposes, EOP), angielski dla celów akademickich (English for Academic Purposes, EAP) (J.C. Richards/ T.S. Rodgers 2001).

pidżynowym (pidgin/pidgin language) lub kreolskim (creole/creole language).

${ }^{27}$ K. Bakuła (2010) proponuje tłumaczenie ,język wzdłuż i wszerz programu”. 


\section{Bibliografia}

Bailey, B. (2001), Dominican-American ethnic/racial identities and United States social categories, (w:) International Migration Review, 35 (3), 677-708.

Bakuła, K. (2010), Nauczanie języka angielskiego jako ojczystego w Anglii. Ze szczególnym uwzględnieniem gramatyki, (w:) Acta Universitatis Wratislaviensis, 8 (18), 55-66.

Bhatia, T.K./ W.C. Ritchie (red.) (2004), The handbook of bilingualism. Oxford.

Bialystok, E. (2001), Bilingualism in development. Language, literacy, and cognition. Cambridge.

Bloomfield, L. (1973), Language. London.

Bouchard Ryan, E./ H. Giles (red.) (1982), Attitudes towards language variation: social and applied contexts. London.

Brinton, D. M./ M. A. Snow/ M. B. Wesche (1989), Content-based second language instruction. New York.

Brown, H. D. (1994), Principles of language learning and teaching. Englewood Cliffs, NJ.

Döpke, S. (1992), One parent one language. An interactional approach. Amsterdam.

Ervin, S./ C. Osgood (1954), Psycholinguistics: a survey of theory and research problems, (w:) C. Osgood/ T. Seboek (red.), Psycholinguistics, 139-146.

Europejski system opisu kształcenia językowego: uczenie się, nauczanie, ocenianie, (2003), H. Komorowska (red. nauk.). Warszawa.

Genesee, F. (1987), Learning through two languages: studies of immersion and bilingual education. Cambridge, MA.

Genesee, F. (1994), Educating second language children: the whole child, the whole curriculum, the whole community. New York.

Gębal, P. E. (2008), W stronę podstaw dydaktyki języka polskiego jako obcego. Próba bilansu polonistycznej myśli glottodydaktycznej, (w:) W. T. Miodunka/ A. Seretny (red.), W poszukiwaniu nowych rozwiązań. Dydaktyka języka polskiego jako obcego u progu XXI wieku. Kraków, 79-88.

Grosjean, F. (1982), Life with two languages. An introduction to bilingualism. Cambridge.

Grosjean, F. (1989), Neurolinguists, beware! The bilingual is not two monolinguals in one person, (w:) Brain and Language, 36, 3-15.

Grosjean, F. (2010), Bilingual: life and reality. London.

Grucza, F. (1981), Glottodydaktyczne implikacje bilingwizmu, (w:) F. Grucza (red.), Bilingwizm a glottodydaktyka. Warszawa, 9-35.

Grucza, F. (2013a), Lingwistyka stosowana. Historia - Zadania-Osiagnięcia. Warszawa.

Grucza, F. (2013b), Stratyfikacyjny model budowy i diakryzy języków ludzkich. Warszawa.

Grucza, S. (2013a), Lingwistyka języków specjalistycznych. Warszawa.

Grucza, S. (2013b), Od lingwistyki tekstu do lingwistyki tekstu specjalistycznego. Warszawa.

Klein W. (1986), Second language acquisition. Cambridge.

Klima, E. S.,/ U. Bellugi (1979), The signs of language. Cambridge, MA.

Kurcz, I. (2007), Psychologiczne aspekty dwujęzyczności. Gdańsk. 
Lam, A. (2006), Bilingualism, (w:) R. Carter/ D. Nunan (red.), The Cambridge guide to teaching English to speakers of other languages. Cambridge, 93-99.

Laskowski, R. (2009), Język w zagrożeniu. Przyswajanie języka polskiego w warunkach polsko-szwedzkiego bilingwizmu. Kraków.

Laskowski, R. (2014), Language maintenance-language attrition. The case of Polish children in Sweden. Frankfurt am Main.

Leopold, W.F. (1939-49), Speech development of a bilingual child. Vols. I-IV. Evanston, Ill.

Liebscher, G./ J. Dailey-O'Cain (2005), Learner code-switching in the content-based foreign language classroom, (w:) The Modern Language Journal, 89, 234-247.

Lipińska. E./ A. Seretny (2012), Między językiem ojczystym a obcym. Nauczanie $i$ uczenie się języka odziedziczonego na przykładzie chicagowskiej diaspory polonijnej. Kraków.

Lipińska, E. (2013), Polskość w Australii. O dwujęzyczności, edukacji i problemach adaptacyjnych Polonii na antypodach. Kraków.

Majer, J. (2003), Interactive discourse in the foreign language classroom. Łódź.

Marsh, D. (1994), Bilingual education \& content and language integrated learning. Paris.

Miodunka, W. T. (2009), Lingwistyka stosowana a nauczanie języka polskiego jako obcego, (w:) Lingwistyka Stosowana 1, 61-80.

Miodunka, W. T. (2010), Polszczyzna jako język drugi. Definicja języka drugiego, (w:) J. S. Gruchała/ H. Kurek (red.), Silvarerum philologicarum. Studia ofiarowane Profesor Marii Strycharskiej-Brzezinie z okazji Jej jubileuszu. Kraków, 233-245.

Nocoń, J. (2012), Problemy i dylematy współczesnej lingwodydaktyki języka polskiego, (w:) Lingwistyka Stosowana/ Applied Linguistics/ Angewandte Linguistik, 5, 49-64.

Olpińska-Szkiełko, M. (2013a), Nauczanie dwujęzyczne w świetl badań glottodydaktycznych. Warszawa.

Olpińska-Szkiełko, M. (2013b), Wychowanie dwujęzyczne w przedszkolu. Warszawa.

Paradis, M. (2000). The neurolinguistics in the next decades, (w:) Brain and Language, $71,178-180$.

Paradis, M. (2004). A neurolinguistic theory of bilingualism. Amsterdam.

Peal, E./ W. E. Lambert (1962), The relation of bilingualism to intelligence, (w:) Psychological Monographs: General and Applied, 76 (27), 1-23.

Peal, E. / W. E. Lambert (2007), Związek dwujęzyczności z inteligencja, (w:) I. Kurcz (red.), Psychologiczne aspekty dwujęzyczności. Gdańsk, 230-268.

Richards, J. C. / T. S. Rodgers (2004) (2. wyd.), Approaches and methods in language teaching. Cambridge.

Romaine, S. (1989), Bilingualism. Oxford.

Ronjat, J. (1913), Le développement du langage observé chez un enfant bilingue. Paris.

Sokol, J., (2015), Europejska wielojęzyczność, (w:) Języki Obce w Szkole. Sięgnij po Języki!, 21-27.

Spolsky, B. (1998), Sociolinguistics. Oxford.

Swain, M. (1978), Home-school language switching, (w:) J. C. Richards (red.), Understanding second and foreign language learning. Issues and approaches. Rowley, MA.

Weinreich, U. (1953), Languages in contact. New York. 